\title{
Fluorometer Controlled Apparatus Designed for Long-Duration Algal-Feeding Experiments and Environmental Effect Studies with Mussels
}

\author{
Daniel Pleissner, Kim Lundgreen, Florian Lüskow, and Hans Ulrik Riisgård \\ Marine Biological Research Centre, University of Southern Denmark, Hindsholmvej 11, 5300 Kerteminde, Denmark \\ Correspondence should be addressed to Hans Ulrik Riisgård; hur@biology.sdu.dk
}

Received 15 February 2013; Accepted 9 May 2013

Academic Editor: Norman Ying Shiu Woo

Copyright (C) 2013 Daniel Pleissner et al. This is an open access article distributed under the Creative Commons Attribution License, which permits unrestricted use, distribution, and reproduction in any medium, provided the original work is properly cited.

\begin{abstract}
Experimental feeding and growth studies on filter-feeding organisms often rely on constant algal concentrations maintained over extended periods of time. Here we present a fluorometer controlled apparatus (FCA) designed for feeding experiments with suspension-feeding mussels at naturally low chlorophyll $a$ concentrations above $0.5 \mu \mathrm{g} \mathrm{L}$. The principle used is feedback regulation of the algal concentration based on continuous monitoring of the fluorescence intensity of chlorophyll $a$ in water pumped through the apparatus from an aquarium with mussels. The filtration rate is monitored continuously as the rate of change of measured volume of an algal stock added to the aquarium for keeping a constant algal concentration. As an example, the FCA has been used to study the filtration rates of blue mussels (Mytilus edulis) at algal concentrations both near and above the incipient saturation level for reduced filtration activity. As another example to put the FCA into perspective as a reliable method for environmental effect studies, the apparatus has been used to demonstrate the acute effect of changing salinity on the filtration rate of M. edulis.
\end{abstract}

\section{Introduction}

Bioenergetic and feeding-behavioural studies on filterfeeding organisms may often rely on supply of feed algae maintained at constant concentrations over extended periods of time. In the case of the blue mussel (Mytilus edulis) algal concentrations below a lower critical level [1-5] and above an upper critical saturation concentration (about $6 \mu \mathrm{g}$ chlorophyll $a(\operatorname{chl} a) \mathrm{L}^{-1}$; see minireview by Riisgård et al. [6]) lead to partial shell closure and reduced filtration rate.

The feeding behaviour of Mytilus edulis was studied by Riisgård et al. [6] using the so-called steady-state method (e.g., [7]) at different well-defined but relatively high algal concentrations eventually leading to reduced filtration rate. Thus, the upper algal concentration at which the mussel exploits its filtration capacity over an extended period of time was identified by stepwise raising the steady-state algal concentration, and the threshold concentration for incipient "saturation reduction" of the filtration rate was found to be between 5,000 and 8,000 (Rhodomonas salina) cells $\mathrm{mL}^{-1}$, equivalent to 6.3 and $10.0 \mu \mathrm{g}$ chl $a \mathrm{~L}^{-1}$, respectively [6].
However, the steady-state method can only be used to ensure a constant algal concentration between the lower and upper critical algal concentration where the filtration rate is constant [7]. Therefore, a more sophisticated feedback-controlled apparatus is needed for maintaining a well-defined algal concentration in feeding and growth experiments with mussels at algal concentrations above the threshold concentration for incipient saturation reduction where filtration rate is not constant. Likewise, such an apparatus may have advantages in, for example, studies where changing environmental conditions, such as varying salinity of the ambient water, cause reduced valve-opening degree and thus reduced filtration rate.

The steady-state method has restricted previous longterm feeding and growth experiments with mussels to be conducted at algal concentrations below the saturation concentration [6, 8-11]. Other mussel studies, however, have been restricted to very high algal concentrations (e.g., [12$15]$ ), presumably due to limited sensitivity of the feedback control systems. Most of the described control systems are based on measurements of turbidity, and low sensitivity of photoelectric cells seems to have been the major drawback 
in continuous automatic-recording apparatus [12, 13, 15-17]. The sensitivity of the detector was improved by Hornbach et al. [18], who used a fiber-optic colorimeter with possible adjustment of the light pathway according to the particle concentration for clearance rate measurements, or even more sophisticated by Breteler and Lann [19], who used an electronic particle counter as sensing unit. Furthermore, fluorescence where the emission of light of specific algal pigments after excitation is detected was used by Gallager and Mann [20] for measurements of grazing activity of mollusk larvae. More recently, Rico-Villa et al. [21] presented a flowthrough rearing system for oyster larvae using a fluorescence sensor for monitoring the ingestion rate of the larvae.

Here, we present a new fluorometer controlled apparatus (FCA) designed not only for running long-duration feeding experiments with mussels fed algal cells at naturally occurring chl $a$ concentrations but also for studying how varying salinity (and other environmental factors) may affect the filtration rate of mussels. The principle used is feedback regulation of the algal concentration, based on continuous monitoring of the fluorescence intensity of $\operatorname{chl} a$ in water samples pumped through the apparatus from the experimental aquarium with mussels. The filtration rate is monitored continuously by measurement of the volume of an algal stock added to the aquarium for keeping the algal concentration constant. As an important example of the applicability we have used the FCA for a detailed investigation of the feeding rate of Mytilus edulis at algal concentrations near and above the upper incipient saturation level. Another example dealing with the acute effect of changing salinity on the filtration rate of $M$. edulis puts the FCA into perspective as a reliable method for environmental effect studies.

\section{Materials and Methods}

2.1. Description of Fluorometer Controlled Apparatus (FCA). The apparatus maintains a defined concentration in an aquarium with filter-feeding mussels and a constant throughflow by adding concentrated algal suspension to replace the amount of algal cells removed (Figure 1). The volume of algal suspension added to the aquarium is determined by the filtration activity of mussels and by the wash-out of algal cells with the through-flow caused by a constant input of particle-free seawater which ensures a good water quality. Water from the aquarium with mussels is continuously recycled through a silicon tube to the fluorometer (10AU Fluorometer, Turner Design) containing a flow-through cuvette which enables a continuous measurement of the algal concentration (Figure 1(a)). The specific wavelengths for excitation $(430 \mathrm{~nm})$ and emission $(680 \mathrm{~nm})$ are chosen for the characteristic pigment ( $\mathrm{chl} a$ ) of the algal strain (Rhodomonas salina) used as feed. The analog output of the fluorometer is connected via an A/D converter to a computer (Figure 1(b)). A program written in Microsoft C\#.net creates a pulse with modulation ( 1 pulse every $6 \mathrm{~s}$ and a duty cycle from 0 to $100 \%$ in step of $0.1 \mathrm{~s}$ ) of the digital output Port B0 on the PMD-1208 as a function of the measured algal concentration in the tank. Port B0 is connected to a driver circuit to switch a standard USB mains relay (Figure 1(b)). Correlation between fluorescence intensity and algal concentration is given by a calibration row. If the algal concentration is below a defined level the mains relay starts a peristaltic pump that pumps a suspension of concentrated algae from the stock into the aquarium to keep the algal concentration constant. Measured and average data are displayed in a TextBox every sec. Average of the data is recorded in a ListBox with an arbitrary TimeStamp. The data are recorded as a text file.

2.2. Filtration Rate of Mussels. When using the clearance method, to cross-check the filtration rates estimated from the FCA, the dosing pump of the FCA maintaining a constant algal concentration in the aquarium was stopped and filtration rates were measured as the volume of water that was cleared of suspended particles per unit of time. The reduction in the number of particles as a function of time was followed either by measuring the fluorescence or by taking water samples $(10 \mathrm{~mL})$ at fixed time intervals and measuring the particle concentration with an electronic particle counter (Elzone 5380) in the aquarium with mussels and well-mixed seawater to which were added algal cells (Rhodomonas salina, diameter about $6.7 \mu \mathrm{m}$ ). These are $100 \%$ efficiently retained by the gills of the mussels (i.e., cell diameter larger than $4 \mu \mathrm{m}$ [22]) therefore clearance rate equals filtration rate. The clearance rate $\left(F_{\mathrm{CR}}\right)$ was determined from the exponential decrease in algal concentration as a function of time using the usual clearance formula (e.g., [23-25]): $F_{\mathrm{CR}}=(V / t n) \times$ $\ln \left(C_{0} / C_{t}\right)=V / n \times$ slope of regression line $(b)$ in a semi-ln plot for the reduction in algal concentration with time in a well-mixed aquarium:

$$
F_{\mathrm{CR}}=\frac{V b}{n}
$$

where $C_{t}$ and $C_{0}$ are terminal and initial concentrations of particles, $V$ is the water volume in aquarium, and $n$ is the number of mussels. A control experiment without mussels showed that sedimentation of algal cells was insignificant.

When using the FCA presented here, filtration rates were estimated by means of the following equation [11]:

$$
F=\frac{\left[P \times C_{s}-(P+F l) \times C_{a}\right]}{C_{a} \times n},
$$

where $P$ is the pumping rate of algal-dosing pump, calculated from the total volume of algal stock suspension (TV) added to the aquarium per unit of time $(t)$, that is, $P=d(T V) / d t$; $n$ is the number of mussels, $C_{s}$ is the algal concentration in stock suspension, $C_{a}$ is the algal concentration in well-mixed aquarium, and $F l$ is the flow-through rate of bio-filtered seawater measured as volume of collected out-flow water over a known time period.

2.3. Experimental Mussels. Blue mussels, Mytilus edulis, were collected in Kerteminde Fjord, Denmark, and acclimated for one week in the laboratory at the Marine Biological Research Centre (University of Southern Denmark) prior to the experiments. The mussels were kept in aerated flowthrough tanks supplied with seawater from the fjord inlet until they were transferred to the experimental aquarium. 


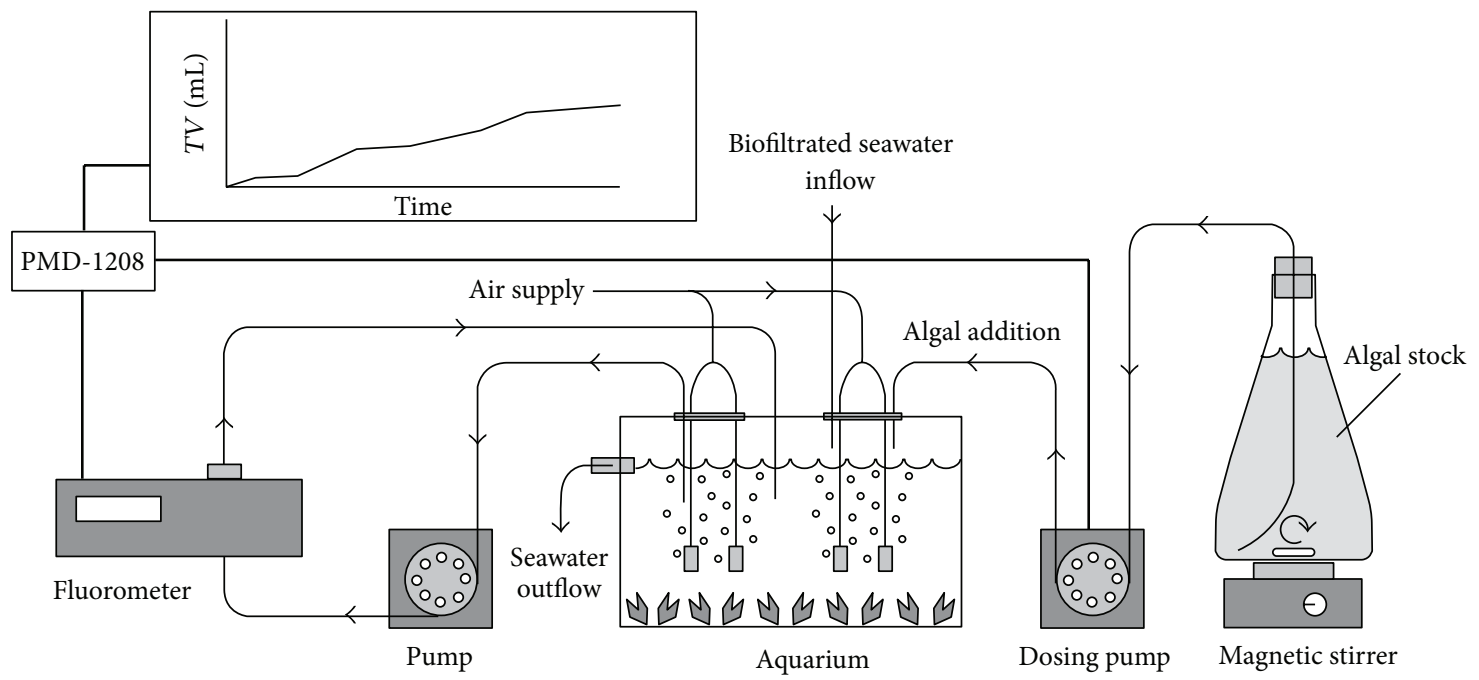

(a)

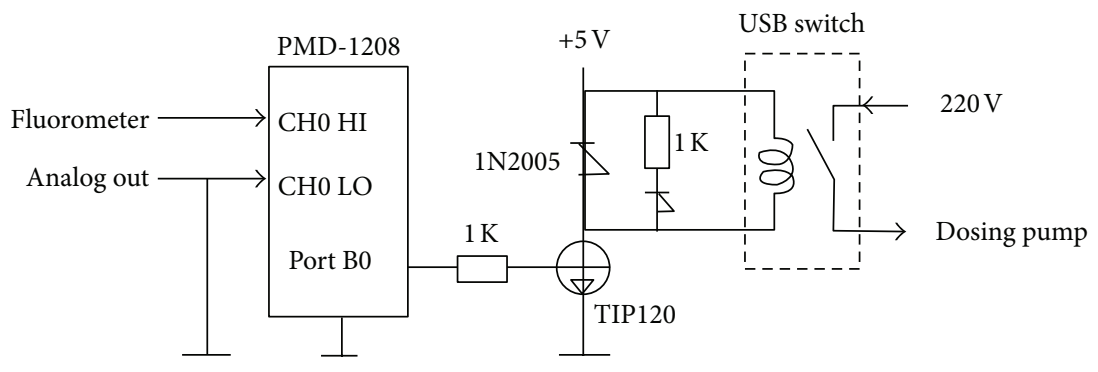

(b)

FIGURE 1: Fluorometer controlled apparatus (FCA). (a) Schematic drawing of automatic recording apparatus for continuous measurement of filtration rate of mussels at constant algal concentration. Biofiltrated seawater is flowing through a well-mixed aquarium with blue mussels, Mytilus edulis, at a constant rate. Water from the aquarium is continuously pumped through a cuvette in the fluorometer monitoring the algal concentration and back again into the aquarium. When the algal concentration decreases below a fixed trigger level, the dosing pump is activated to add algal suspension from a stock. The total volume (TV) of an algal suspension added over time is stored automatically. (b) Circuit scheme of apparatus. Analog output of fluorometer is connected via an A/D converter (12 bit A/D input of the PMD-1208LS USBbased personal measurement device from measurement computing) to a computer. The measured fluorescence of suspended algal cells in the aquarium correlates with a known cell concentration. When the fluorescence comes below a defined lower trigger value Port B0 sends a pulse to the dosing pump and a defined volume of an algal suspension is added into the aquarium.

All experiments were performed at $12.0 \pm 0.3^{\circ} \mathrm{C}$ and $21.8 \pm$ 1.2 psu. Dry weight of soft parts $\left(90^{\circ} \mathrm{C}, 24 \mathrm{~h}\right)$ and shell length were determined for a representative group of at least 10 mussels.

\section{Results}

A number of test experiments were conducted to evaluate the performance of the FCA. The following conversion factor was used: $1 \mu \mathrm{g}$ chl $a \mathrm{~L}^{-1}=1 /\left(1.4 \times 10^{-3}\right.$ ) 700 (Rhodomonas sp.) cells $\mathrm{mL}^{-1}$ which is in agreement with Clausen and Riisgård [10]. All experiments, with and without mussels were performed in prior bio-filtered (by mussels) seawater to ensure that no non-chl $a$ containing particles could mask the results. The bio-filtered seawater was regularly checked for particles using a particle counter (Elzone 5380). After each experiment mussels were allowed to empty their digestive system overnight.
3.1. Maintaining Constant Algal Concentrations. The FCA was tested for its ability to maintain different algal (Rhodomonas salina) concentration levels in an aquarium diluted by a constant through-flow of biofiltrated seawater. After initial addition of algal cells to the aquarium to reach a certain high concentration (around 8,000 cells $\mathrm{mL}^{-1}$ ), the dosing pump was stopped and through-flow seawater was allowed to reduce the concentration to lower levels. During the test period, the fluorometer controlled additions of $R$. salina to the aquarium were recorded in order to measure the total volume (TV) of algal stock suspension added. In one case, the constant through-flow of seawater was monitored by means of the fluorometer to follow the exponential decrease in the algal concentration in order to compare the estimated washing-out rate ("clearance rate") with the actual throughflow rate.

From Figure 2 it appears that the FCA precisely maintains different algal concentration levels down to around 400 


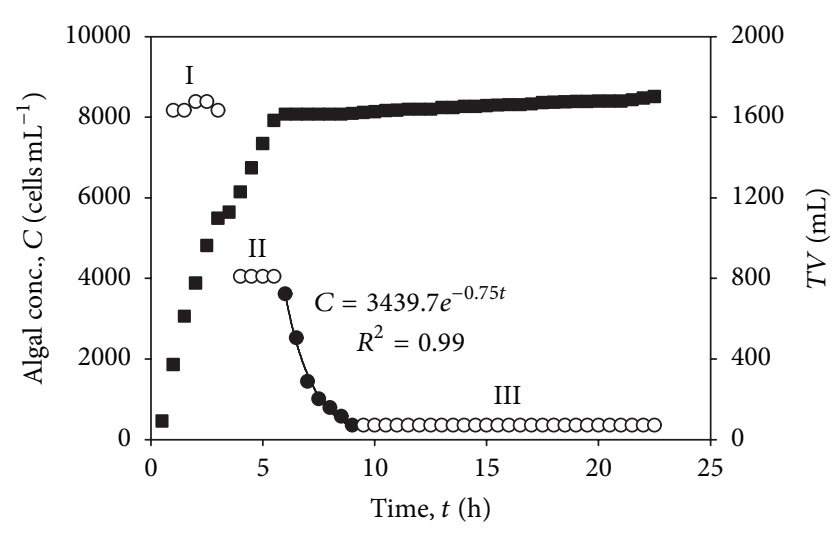

FIGURE 2: Test of fluorometer controlled apparatus (FCA) without mussels maintaining 3 algal (Rhodomonas salina) concentration levels $(C, \bigcirc)$ after initial addition of algal cells to the aquarium $(V=15.4 \mathrm{~L})$ to reach $8,250 \pm 120$ cells $\mathrm{mL}^{-1}(\mathrm{I})$ and subsequent two times washout of algal cells with through-flow seawater to reduce the concentration to (II) $4,120 \pm 430$ and (III) $370 \pm 40$ cells mL $^{-1}$, respectively. The fluorometer controlled addition of $R$. salina to maintain a constant algal concentration in the aquarium over a certain period of time appears from the total volume (TV) of algal suspension added ( $\mathbf{\square})$. Between 6 and $9 \mathrm{~h}$ a constant throughflow of bio-filtered seawater $\left(200 \mathrm{~mL} \mathrm{~min}^{-1}\right)$, which is a measure of "filtration rate," caused an exponential decrease in the algal concentration $(\bullet)$.

Rhodomonas salina cells $\mathrm{mL}^{-1}$ (equivalent to $0.5 \mu \mathrm{g} \operatorname{chl} a \mathrm{~L}^{-1}$ ) over an extended period of time $(>12 \mathrm{~h})$ in an experimental aquarium $(V=15.4 \mathrm{~L})$ without mussels. Similar fluorescence intensities of a suspension with a known algal concentration measured prior to the experiment and afterwards revealed that no microbial growth on the glass wall of the photoelectric cell of the fluorometer, interfering with measurements, occurred. Between 6 and $9 \mathrm{~h}$ a constant through-flow of biofiltered seawater $\left(12 \mathrm{~L} \mathrm{~h}^{-1}\right)$ caused an exponential decrease in the algal concentration, and from the exponent $\left(0.75 \mathrm{~h}^{-1}\right)$ in the shown equation for the exponential curve fit it can be calculated that the decrease in algal concentration is equivalent to a washing-out rate of $(0.75 \times 15.4=) 11.6 \mathrm{~L} \mathrm{~h}^{-1}$ which is close to the actual through-flow rate.

3.2. Determination of Clearance Rate. The ability of the FCA to determine the clearance rate was tested both without and with mussels in the aquarium. First, the exponential decrease in algal concentration in the well-mixed aquarium, caused by the flow-through of seawater diluting the algal concentration, was measured by fluorescence in order to make a semi-ln plot of the decreasing algal concentration in order to estimate the washing-out rate $=$ "clearance rate" $\left(F_{\mathrm{CR}}\right)$ from (1). Next, the decrease in algal concentration in the aquarium caused solely by filtering mussels (i.e., no through-flow of water) was measured using both an electronic particle counter (Elzone 5380) and the fluorometer to lay down the slopes of regression lines expressing the filtration rate of the mussels compare (1).

Figure 3(a) shows two examples of exponential decrease in algal concentration in the experimental aquarium caused solely by flow-through of seawater with rates of 2.1 and
1.2 $\mathrm{L} \mathrm{h}^{-1}$, respectively. Using (1) and slopes of regression lines in the semi-ln plots, it can be calculated that the washing-out rates ("clearance rate") were $(0.14 \times 15.4=) 2.2$ and $(0.06 \times$ $15.4=) 0.9 \mathrm{~L} \mathrm{~h}^{-1}$, respectively, in reasonably good agreement with the actual flow-through rates. Figure 4(b) shows the exponential decrease in algal concentration in the aquarium caused solely by 8 filtering mussels (mean \pm S.D. shell length $=$ $28.0 \pm 1.3 \mathrm{~mm}$ ). Using (1) and the slope of the regression lines it is estimated that the filtration rate of mussels exposed to 40,000 cells $\mathrm{mL}^{-1}$ was $(0.0024 \times 15.4 \times 60 / 8=) 0.3 \mathrm{~L} \mathrm{~h}^{-1}$ ind. ${ }^{-1}$, irrespective of the method used for measuring the algal concentration. At 40,000 cells $\mathrm{mL}^{-1}$ where appearance of excreted products was seemingly high, no difference between measurement of exponential decrease in algal concentration using the FCA and the electronic particle counter was seen within at least $90 \mathrm{~min}$ (Figure 3(b)).

3.3. Test of Design. The FCA method for calculation of filtration rate using the dosing-pump rate $(P)$ in $(2)$ was tested for different number of mussels in the experimental aquarium. In Figure 4 it is seen that the $T V$ of an algal stock added to the aquarium to maintain a constant algal concentration of 4,380 cells $\mathrm{mL}^{-1}$ progressively responded (Figure 4(a)) from 15, 9, and 3 mussels as the $P$ of algal stock decreases while the measured mean filtration rates of 15,9 , and 3 mussels of $0.61,0.60$, and $0.55 \mathrm{~L} \mathrm{~h}^{-1}$ ind. ${ }^{-1}$, respectively, are almost identical (Figure 4(b)). This indicates that the experiment was properly designed and water was sufficiently mixed by the 4 air stones to ensure instantaneous mixing of the exhalant water in the whole water volume of the aquarium which is a prerequisite for using both (1) and (2).

3.4. Filtration Activity of Mussels. The filtration rate of different sized mussels was measured by means of the FCA according to (2) in experiments performed under "optimum conditions" (i.e., fully open mussels). Furthermore, to highlight the applicability of the FCA near saturation levels and above, the saturation-caused reduction of the filtration rate of mussels exposed to different relatively high Rhodomonas salina concentrations (about 6,000, 7,000, 8,000, $9,000,10,000,12,000,20,000$, and 36,000 cells $\mathrm{mL}^{-1}$ ) was studied for up to $24 \mathrm{~h}$. Additionally, to study the filtration rate at saturation conditions over a long period an experiment at 8,160 cells $\mathrm{mL}^{-1}$ was performed for $10 \mathrm{~d}$ and compared to filtration rates of unrestricted mussels as a control.

The filtration rates measured on 4 groups of mussels (Table 1) exposed to different Rhodomonas salina concentrations are shown in Figure 5. Initially, the mussels were exposed to a relatively low algal concentration (about 2,300 cells $\mathrm{mL}^{-1}$ ) to stimulate the mussels to fully open their valves and to exploit their filtration rate capacity which was used as a reference when the algal concentration was subsequently increased to different higher algal concentrations that were maintained during the following about 12 to $24 \mathrm{~h}$. During the initial period with "optimum conditions" (open triangles, Figure 5) the filtration rate $\left(F, \mathrm{~L} \mathrm{~h}^{-1}\right)$ of the mussels increased with increasing shell length $(L, \mathrm{~mm})$ according to $F=0.0024 L^{2.01}$ (Figure 6) and was in good agreement 


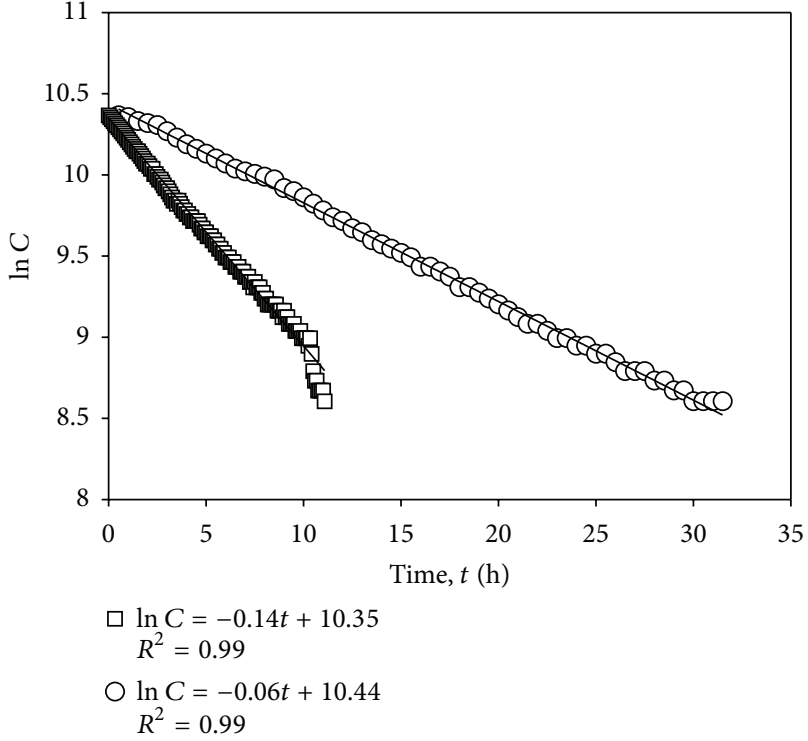

(a)

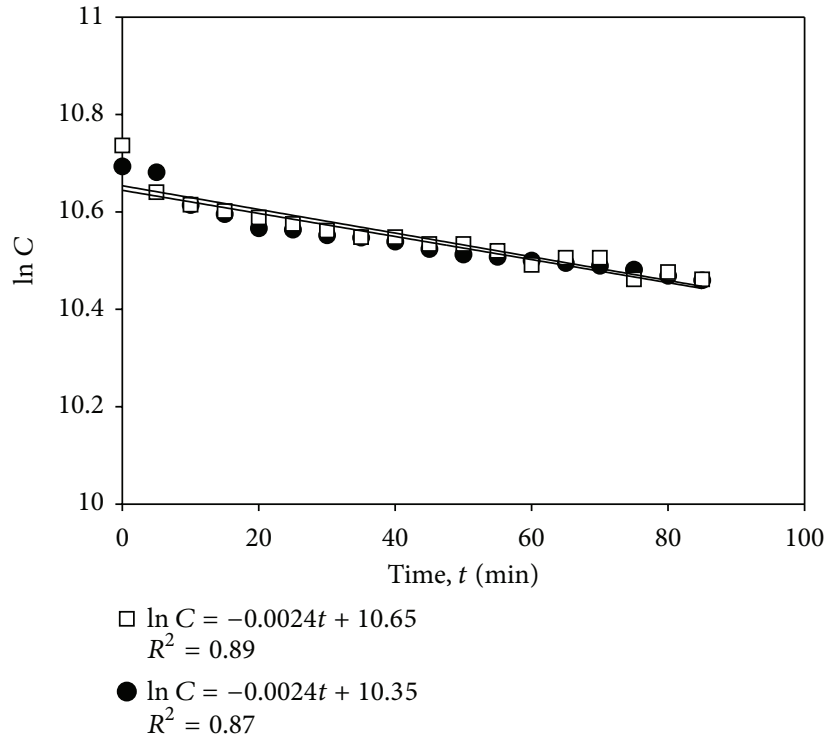

(b)

Figure 3: Test of fluorometer controlled apparatus (FCA). (a) Two examples of exponential decrease in algal concentration $\left(C_{0}=\right.$ around 40,000 cells $\left.\mathrm{mL}^{-1}\right)$ in experimental aquarium $(V=15.4 \mathrm{~L})$ caused by flow-through of biofiltrated seawater $\left(\square, 2.1\right.$ and $\left.\bigcirc, 1.2 \mathrm{~L} \mathrm{~h}{ }^{-1}\right)$ diluting the algal concentration measured by fluorescence. The slopes of the regression lines in the semi-ln plot express the flow-through rate, compare (1). (b) Exponential decrease in algal concentration in aquarium caused only by filtering mussels (mean \pm S.D., shell length $=28.0 \pm 1.3 \mathrm{~mm}$ ). The algal concentration was measured using both an electronic particle counter $(\bullet)$ and the FCA $(\square)$. The slopes of the regression lines express the filtration rate of the mussels $\left(n=8, \square\right.$ and $\left.\bullet=0.3 \mathrm{~L} \mathrm{~h}^{-1}\right)$, compare (1).

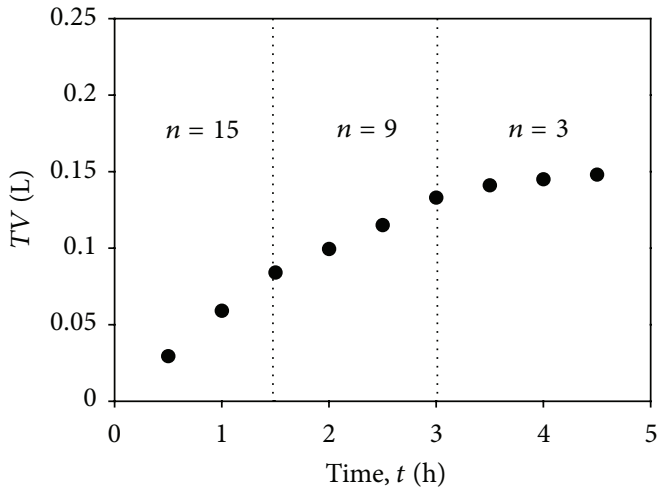

(a)

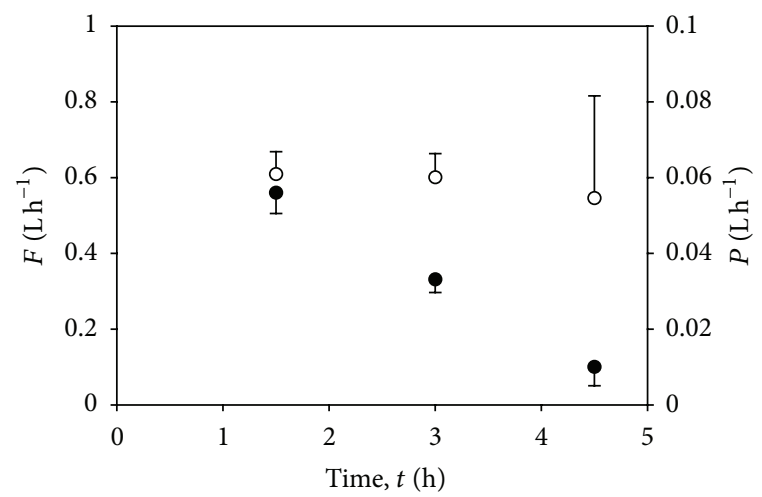

(b)

FIGURE 4: Test of fluorometer controlled apparatus (FCA). Measurement of filtration rate with a varying number of mussels placed in the experimental aquarium. (a) Total volume of algal suspension added $(T V, \bullet)$ when an algal stock suspension $\left(0.72 \times 10^{6} \mathrm{cells}_{\mathrm{mL}}^{-1}\right)$ is used for keeping the algal concentration in the aquarium constant $\left(4,380 \pm 590\right.$ cells $\left.\mathrm{mL}^{-1}\right)$. Initially, 15 mussels (mean \pm S.D., shell length $=$ $21.1 \pm 1.5 \mathrm{~mm}$ ) were used; later after $1.5 \mathrm{~h}$ the number of mussels was reduced to 9 , and further after $3 \mathrm{~h}$ to 3 mussels. (b) Calculated filtration rate $(F, \bigcirc)$ based on recorded dosing-pump rate of algal stock $(P, \bullet)$ at the end of each period according to (2).

with the relationship found by Kiørboe and Møhlenberg [26] who used the "suction method" and a mixture of suspended bottom material and the unicellular algae Phaeodactylum tricornutum, namely, $F=0.0012 L^{2.14}$, and recently by Riisgård et al. [25] who used the "clearance method" and found the equation to be $F=0.001 L^{2.262}$. These findings, along with the present supplementary measurements by means of the clearance method (Figure 5), inspire confidence that the FCA provides reliable measurements of the filtration rate. During the next period with increased algal concentrations, the filtration rate gradually decreased along with reduced valve opening irrespectively of the size of mussels (Figure 5). The decrease in filtration rate $\left(F_{24}, \mathrm{~L} \mathrm{~h}^{-1}\right)$ with time $(t=24 \mathrm{~h})$ in most of the experiments could be described by an exponential function: $F_{24}=c \times \exp (-d \times t)$, where the coefficients $c$ and $d$ (Table 1) were obtained from curve-fits (Figure 5). At 6,400 cells $\mathrm{mL}^{-1}$ the filtration rate was within $24 \mathrm{~h}$ reduced to $48 \%$ and between 6,800 and 10,900 cells $\mathrm{mL}^{-1}$ to about 


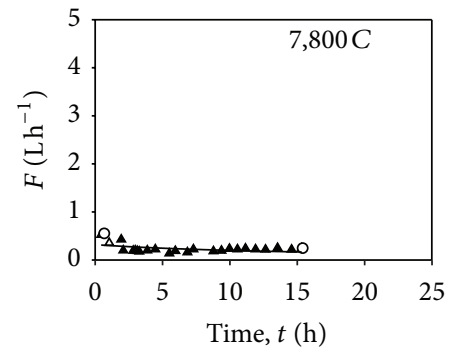

(a)

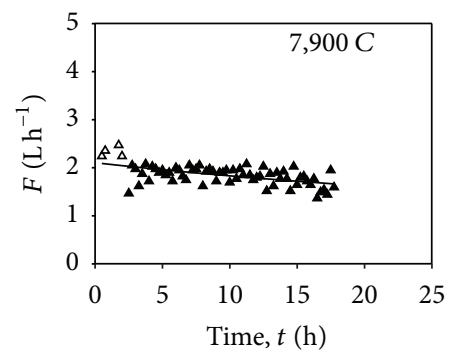

(d)

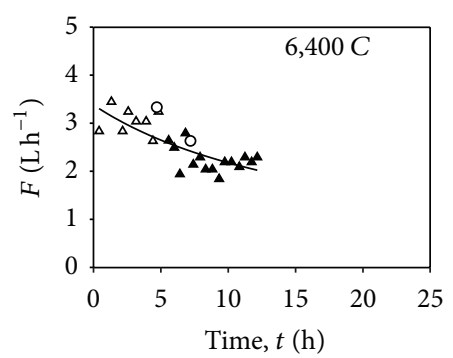

(g)

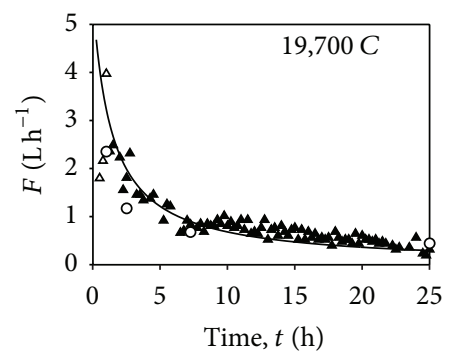

(j)

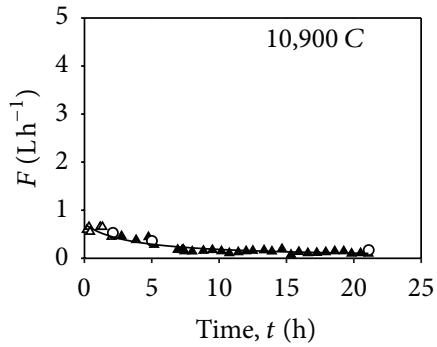

(b)

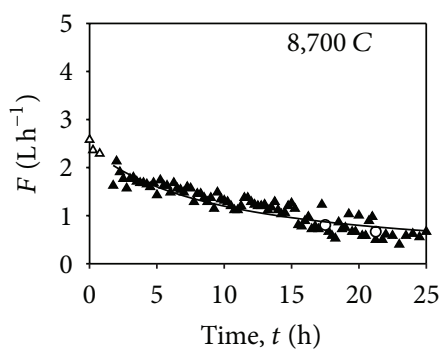

(e)

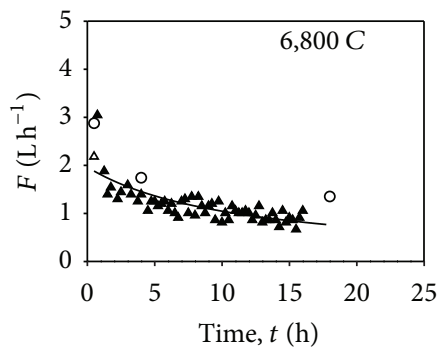

(h)

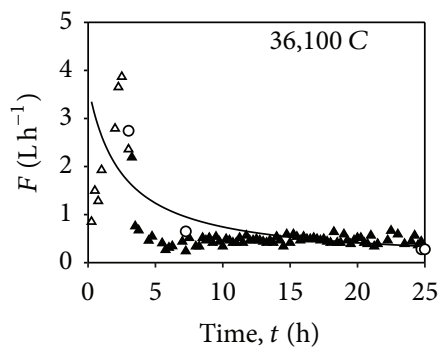

(k)

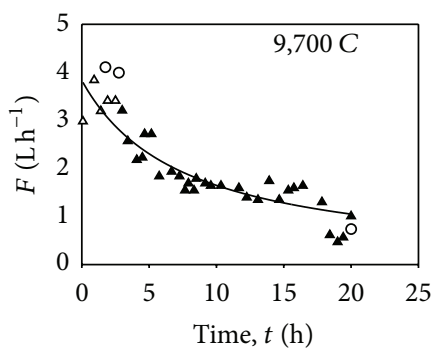

(m)

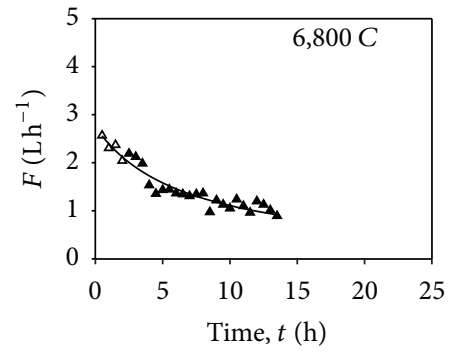

(c)

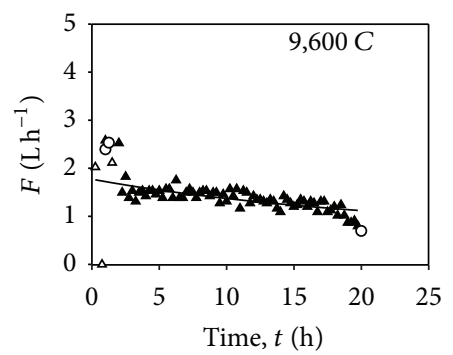

(f)

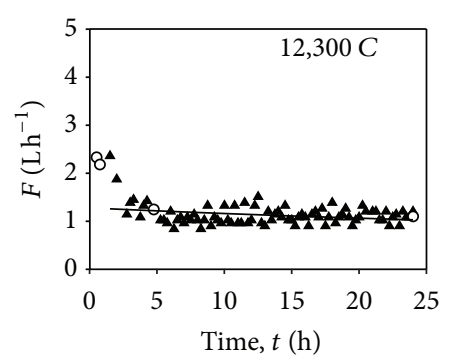

(i)

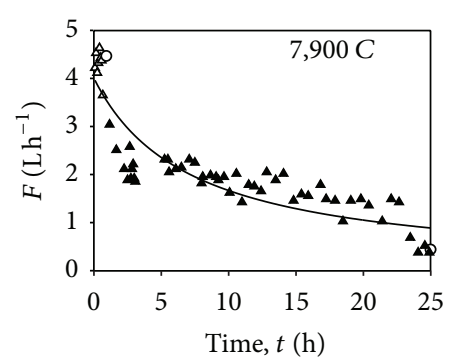

(l) (Group I = (a) and (b); Group II = (c), (d), (e), (f), and (g); Group III = (h), (i), (j), (k), and (l); Group IV = (m), see Table 1). The mussels were initially exposed to a relatively low algal (Rhodomonas salina) concentration ( $\triangle$, about 2,300 cells $\mathrm{mL}^{-1}$ ) to measure the maximum filtration rate, whereupon the algal concentrations were increased to different higher levels as indicated in the subfigures $\left(C\right.$, cells $\left.\mathrm{mL}^{-1}\right)$. Supplementary, filtration rates were regularly measured by the clearance rate method $(\bigcirc,(1))$. 
TABLE 1: Mytilus edulis. Filtration rate $\left(F_{0}\right)$ initially measured by the fluorometer controlled apparatus (FCA) on 4 groups of mussels under optimum conditions (about 2,300 cells $\left.\mathrm{mL}^{-1}\right)$, and estimated filtration rate $\left(F_{24}\right)$ of the same mussels after $t=24 \mathrm{~h}$ exposure to different constant algal (Rhodomonas salina) concentrations $\left(C\right.$, cells $\left.\mathrm{mL}^{-1}\right)$. The coefficients $c$ and $d$, and coefficient of determination $\left(R^{2}\right)$ were obtained from exponential curve-fits according to the equation $F_{24}=c \times \exp (-d \times t)$ for data shown in Figure 5 (\#). Condition index $(\mathrm{CI})=W(\mathrm{~g}$ dry weight of soft parts $) / L(\mathrm{~cm})^{3}$.

\begin{tabular}{|c|c|c|c|c|c|c|c|c|}
\hline $\begin{array}{l}\text { Group } \\
\text { Shell length }(L) \\
\text { Dry weight }(W) \\
\text { Condition index }(\mathrm{CI})\end{array}$ & $\#$ & $\begin{array}{c}C \\
\left(\times 10^{3} \text { cells } \mathrm{mL}^{-1}\right)\end{array}$ & $c$ & $d$ & $R^{2}$ & $\begin{array}{c}F_{0} \\
\left(\mathrm{Lh}^{-1}\right)\end{array}$ & $\begin{array}{c}F_{24} \\
\left(\mathrm{Lh}^{-1}\right)\end{array}$ & $\begin{array}{c}F_{24} / F_{0} \\
(\%)\end{array}$ \\
\hline I & & $2.4 \pm 0.2$ & & & & $0.5 \pm 0.2$ & & \\
\hline $\begin{array}{l}L=15.3 \pm 0.4 \mathrm{~mm} \\
W=0.014 \pm 0.002 \mathrm{~g} \\
\mathrm{CI}=3.9 \pm 0.7 \mathrm{~g} \mathrm{~cm}^{-3}\end{array}$ & $\begin{array}{l}\mathrm{A} \\
\mathrm{B}\end{array}$ & $\begin{array}{c}7.8 \pm 0.4 \\
10.9 \pm 0.6\end{array}$ & $\begin{array}{l}0.28 \\
0.64\end{array}$ & $\begin{array}{l}0.03 \\
0.13\end{array}$ & $\begin{array}{l}0.1 \\
0.9\end{array}$ & & $\begin{array}{l}0.1 \\
0.1\end{array}$ & $\begin{array}{l}20 \\
20\end{array}$ \\
\hline II & & $2.3 \pm 0.2$ & & & & $2.6 \pm 0.3$ & & \\
\hline \multirow{4}{*}{$\begin{array}{l}L=30.4 \pm 1.0 \mathrm{~mm} \\
W=0.219 \pm 0.028 \mathrm{~g} \\
\mathrm{CI}=6.2 \pm 0.5 \mathrm{~g} \mathrm{~cm}^{-3}\end{array}$} & $\mathrm{C}$ & $6.8 \pm 0.5$ & 2.48 & 0.08 & 0.9 & & 0.6 & 23 \\
\hline & $\mathrm{D}$ & $7.9 \pm 0.5$ & 2.09 & 0.01 & 0.3 & & 1.6 & 62 \\
\hline & $\mathrm{E}$ & $8.7 \pm 0.6$ & 2.11 & 0.05 & 0.9 & & 0.7 & 27 \\
\hline & $\mathrm{F}$ & $9.6 \pm 0.8$ & 1.75 & 0.02 & 0.3 & & 1.0 & 38 \\
\hline III & & $2.3 \pm 0.3$ & & & & $2.9 \pm 0.4$ & & \\
\hline \multirow{5}{*}{$\begin{array}{l}L=31.8 \pm 0.2 \mathrm{~mm} \\
W=0.279 \pm 0.022 \mathrm{~g} \\
\mathrm{CI}=7.7 \pm 0.6 \mathrm{~g} \mathrm{~cm}^{-3}\end{array}$} & $\mathrm{G}$ & $6.4 \pm 0.4$ & 3.31 & 0.04 & 0.5 & & 1.4 & 48 \\
\hline & $\mathrm{H}$ & $6.8 \pm 0.3$ & 1.73 & 0.05 & 0.6 & & 0.6 & 21 \\
\hline & I & $12.3 \pm 1.4$ & 1.26 & 0.01 & 0.1 & & 0.9 & 31 \\
\hline & $\mathrm{J}$ & $19.7 \pm 2.9$ & 3.15 & 0.13 & 0.6 & & 0.3 & 10 \\
\hline & $\mathrm{K}$ & $36.1 \pm 4.6$ & 3.49 & 0.19 & 0.3 & & 0.3 & 10 \\
\hline IV & & $2.2 \pm 0.1$ & & & & $4.3 \pm 0.4$ & & \\
\hline $\begin{array}{l}L=45.1 \pm 0.1 \mathrm{~mm} \\
W=0.212 \pm 0.022 \mathrm{~g} \\
\mathrm{CI}=2.3 \pm 0.2 \mathrm{~g} \mathrm{~cm}^{-3}\end{array}$ & $\begin{array}{c}\mathrm{L} \\
\mathrm{M}\end{array}$ & $\begin{array}{l}7.9 \pm 0.9 \\
9.7 \pm 1.1 \\
\end{array}$ & $\begin{array}{l}3.53 \\
3.49\end{array}$ & $\begin{array}{l}0.06 \\
0.07\end{array}$ & $\begin{array}{l}0.7 \\
0.8\end{array}$ & & $\begin{array}{l}0.9 \\
0.9\end{array}$ & $\begin{array}{l}21 \\
21\end{array}$ \\
\hline
\end{tabular}

$20 \%$ of their maximum filtration rate previously measured at low algal concentration. Further, mussels exposed to 19,700 cells $\mathrm{mL}^{-1}$ reduced their filtration rate to $10 \%$ of maximum after $24 \mathrm{~h}$ (Table 1). Filtration rates in experiments A, D, F, I and $\mathrm{K}$ (Table 1 and Figure 5) could not be described properly by an exponential curve fit $\left(R^{2}<0.5\right)$ though all measured filtration rates were below maximum (Figure 5). Mussels in experiment $\mathrm{D}$, however, did not reduce their filtration rates to the same extent as found for mussels in other experiments. But it remains clear that further reduction of the filtration rate may take place during prolonged exposure to high algal concentrations. Thus in an experiment with mussels exposed to 8,160 cells $\mathrm{mL}^{-1}$, the filtration rate became reduced to about $12 \%$ after $48 \mathrm{~h}$ and then remained constantly low during the following $10 \mathrm{~d}$ (Figure 7). In this case, the filtration rate as a function of exposure time $(t)$ could be described by the equation: $F=F_{\text {red }}+\left(F_{0}-F_{\text {red }}\right) \exp (-t / \tau)$, where $F_{0}$ is the maximum filtration rate, $F_{\text {red }}$ is the constantly low filtration rate after initial $48 \mathrm{~h}$ saturation reduction, and $\tau$ is the time constant for exponential decrease after incipient saturation reduction.

Algal concentration controlled by the FCA usually varied within 5 to $15 \%$ of a mean value in experiments performed for $15 \mathrm{~h}$ (Table 1 ) and greatest variation within $22 \%$ of a mean algal concentration of 3,310 cells $\mathrm{mL}^{-1}$ was found for the experiment in Figure 7 performed for $10 \mathrm{~d}$. Measured filtration rates varied within 5 to $15 \%$ of a mean, and only once a variation of $40 \%$ was found (Table 1, Group 1 at 2,400 cells $\mathrm{mL}^{-1}$ ).

3.5. Effect of Changing Salinity. The effect of changing salinity on the filtration rate of Mytilus edulis was studied in 4 experiments using 3 different groups of mussels (Table 2). In these experiments either concentrated seawater or demineralized water was flowing through the aquarium with 20 small (29.6 \pm $0.4 \mathrm{~mm}$ ) mussels at a constant rate to increase or reduce salinity which was measured continuously and recorded on a computer. In Figure 8 is shown a typical example of an experiment. It is seen that the filtration rate is unaffected by decreasing salinity down to about 10 psu whereupon the mussels began to close their valves along with cessation of the filtration activity. However, when the salinity was subsequently increased, the normal filtration rate was soon afterwards restored. It was found that the changing rate of the filtration rate was strongly influenced by the salinity changing rate; the faster the salinity was either reduced or increased, 


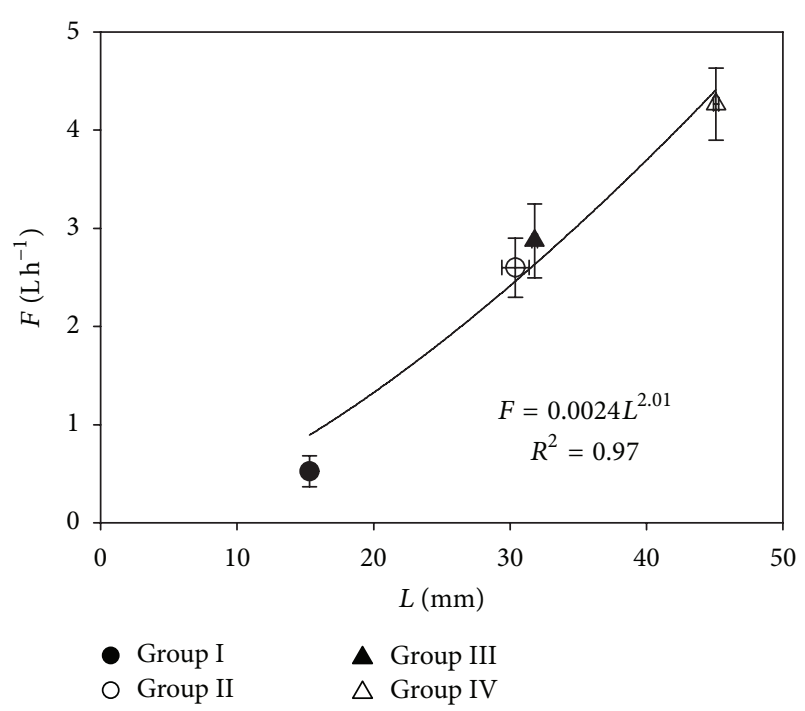

Figure 6: Mytilus edulis. (Mean \pm S.D.) individual filtration rates of mussels measured by the fluorometer controlled apparatus (FCA) when exposed to about 2,300 cells $\mathrm{mL}^{-1}$ during the initial period of experiments shown in Figure 5 as a function of mean shell length $(L)$. Group I $=\bullet ;$ II $=\bigcirc ;$ III $=\boldsymbol{\Delta} ; \mathrm{IV}=\Delta$ (Table 1$)$.

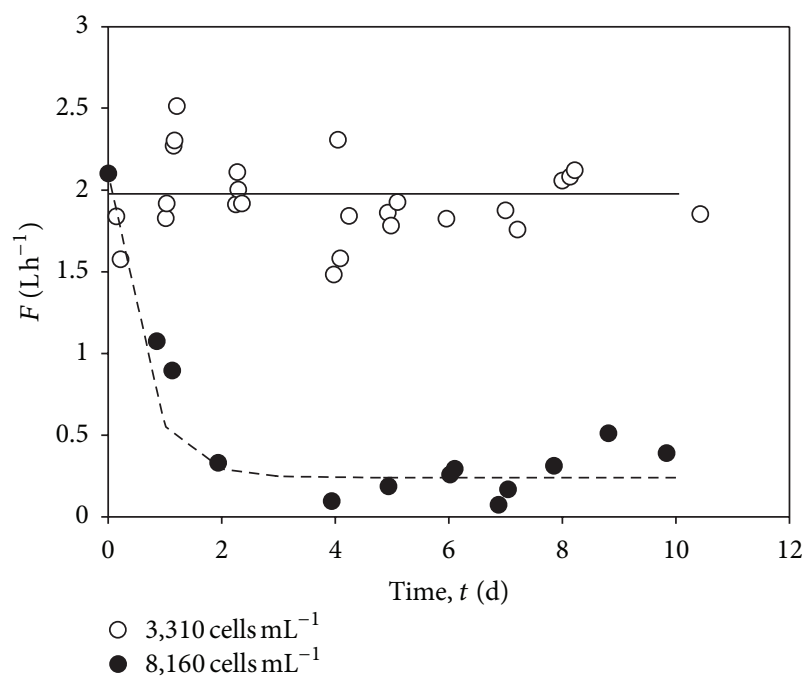

Figure 7: Mytilus edulis. Mean individual filtration rates $(F)$ measured in two groups of mussels $(n=45)$ exposed during $10 \mathrm{~d}$ to $3,310 \pm 730(\bigcirc, L=31.9 \pm 1.3 \mathrm{~mm})$ and $8,160 \pm 1,140$ cells $\mathrm{mL}^{-1}$ $(\bullet, L=32.2 \pm 0.6 \mathrm{~mm})$, respectively. The curve for filtration rates measured at the high algal concentration resulting in saturation reduction was obtained from the following equation: $F=F_{\text {red }}+\left(F_{0}-\right.$ $\left.F_{\text {red }}\right) \times \exp (-t / \tau)$, where $F_{0}=1.9 \pm 0.2 \mathrm{~L} \mathrm{~h}^{-1}, F_{\text {red }}=0.24 \mathrm{Lh}^{-1}$, and $\tau=0.561 \mathrm{~d}$.

the more the change was pronounced in the filtration rate (Table 3 and Figure 9).

\section{Discussion}

The FCA maintained a constant algal concentration in an experimental aquarium with mussels and gave reliable and

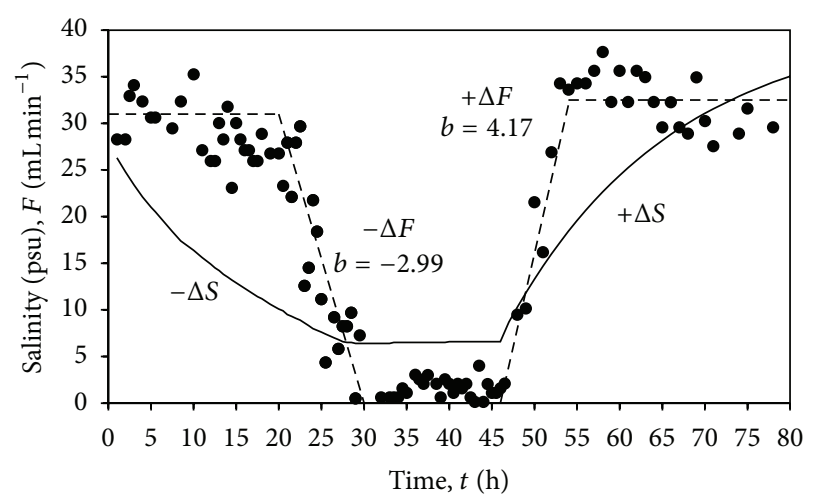

(a)

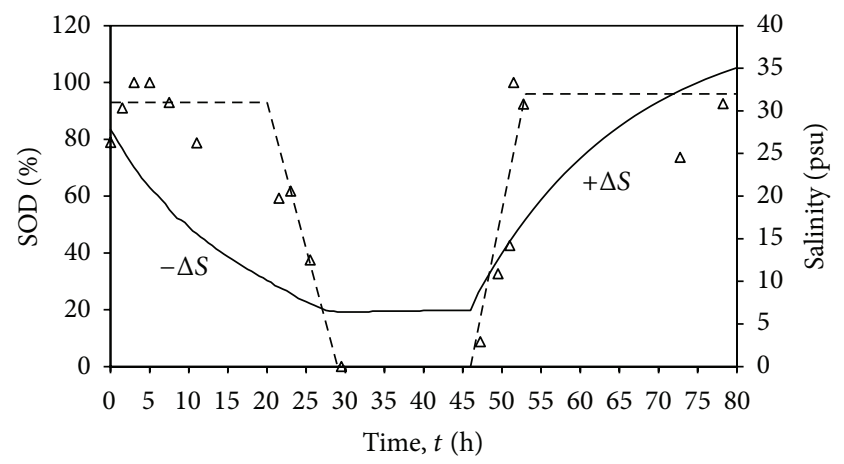

(b)

Figure 8: Mytilus edulis. (a) Salinity changing rates $(\Delta S)$ and simultaneous filtration changing rates $(\Delta F)$ of mussels in Experiment \#2 (see Table 2) (dotted horizontal line fitted by eye; dotted oblique lines $=$ slope of regression line $=b$ ). (b) Shell opening degree (SOD; cf. [25]) of mussels measured from digital pictures taken during the experiment (dotted line fitted by eye).

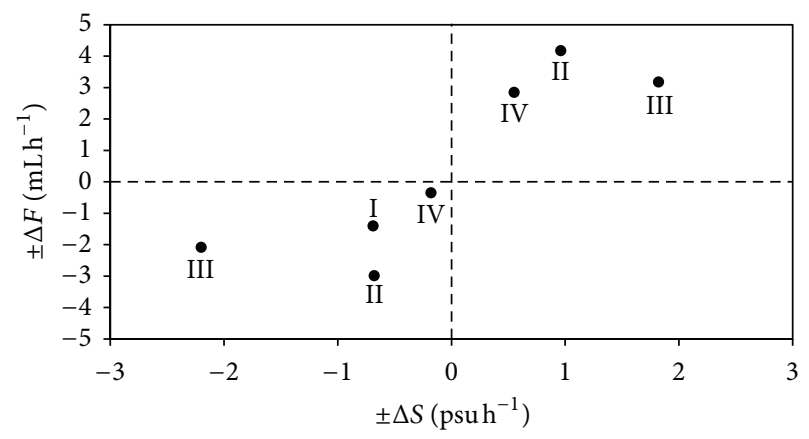

FIGURE 9: Mytilus edulis. Filtration changing rates $(\Delta F)$ of mussels as a function of salinity changing rates $(\Delta S)$ in all experiments based on data from Table 3.

continuously recorded filtration rates and was used for studying the filtration behaviour of mussels at different algal concentrations near and above the critical saturation level, that is, between 5,000 and 8,000 Rhodomonas salina cells $\mathrm{mL}^{-1}$, equivalent to 6.3 and $10.0 \mu \mathrm{g}$ chl $a \mathrm{~L}^{-1}$, respectively [6]. Thus, using the FCA we were able to narrow down the lower algal concentration at which Mytilus edulis eventually 
TABLE 2: Mytilus edulis. Variation in filtration rates $(\Delta F)$ of mussels at different salinity changing rates $(\Delta S)$. Experiments were performed at a mean algal concentration $\left(3,770 \pm 690\right.$ Rhodomonas salina cells $\left.\mathrm{mL}^{-1}\right)$ with three groups of mussels. Number of mussels used in each experiment was 20 and the mean shell length was $29.4 \pm 0.4 \mathrm{~mm}$. For further explanation, see Figure 8.

\begin{tabular}{lccccc}
\hline Experiment \# & Group \# & $-\Delta S\left(\mathrm{psu} \mathrm{h}^{-1}\right)$ & $+\Delta S\left(\mathrm{psu} \mathrm{h}^{-1}\right)$ & $-\Delta F\left(\mathrm{~mL} \mathrm{~min}^{-1} \mathrm{~h}^{-1}\right)$ & $+\Delta F\left(\mathrm{~mL} \mathrm{~min}^{-1} \mathrm{~h}^{-1}\right)$ \\
\hline I & 2 & -0.69 & - & -1.41 & - \\
II & 1 & -0.69 & 0.96 & -2.99 & 4.17 \\
III & 1 & -2.20 & 1.82 & -2.09 & 3.17 \\
IV & 3 & -0.18 & 0.55 & -0.35 & 2.84 \\
\hline
\end{tabular}

TABLe 3: Mytilus edulis. Salinity changing rates $(\Delta S)$ and simultaneous filtration changing rates $(\Delta F)$ of mussels in all experiments (see Table 2 and Figure 8 ).

\begin{tabular}{lcc}
\hline Group & $\Delta S$ & $\Delta F$ \\
\hline I & -0.69 & -1.41 \\
II & -0.68 & -2.99 \\
III & -2.20 & -2.09 \\
IV & -0.18 & -0.35 \\
\hline II & 0.96 & 4.17 \\
III & 1.82 & 3.17 \\
IV & 0.55 & 2.84 \\
\hline
\end{tabular}

reacts by partial valve closure and reduced filtration rate to be between 6,000 and 7,000 R. salina cells $\mathrm{mL}^{-1}$ (Table 1, Figure 5) equivalent to 8.5 to $10.0 \mu \mathrm{g} \mathrm{chl} a \mathrm{~L}^{-1}$ (cf. M\&M), which is higher than what is usually found in the water column in nature [27-36] and much higher than the chl a concentration found over mussel beds [3, 34, 37, 38]. However, in eutrophic and turbid tidal estuaries the chl $a$ concentration may frequently exceed the critical saturation concentration (see below).

The duration time before reduced filtration rate occurred was influenced by extent of increase in algal concentration in the experimental aquarium. Thus, the larger the change in algal concentration was appeared the faster the incipient reduction, in filtration rate, as previously reported for Mytilus edulis [6,39], for the ascidian Ciona intestinalis [40], and for the suspension-feeding polychaete Sabella penicillus [41]. Additionally, the higher the algal concentration, the faster also the reduction of filtration rate, which is confirmed by the high positive value of the correlation coefficient (0.782) between values of $c$ and $d$ in Table 1. It should be emphasized, however, that it is not only the concentration of a certain algal species that determines the incipient reduction in filtration rate, but also the size (volume) of the algal cells used is crucial for the number of cells that can be ingested before the gut capacity is exceeded. Thus, Riisgard et al. [6] found that the total number of $6.9 \mu \mathrm{m}$ diameter Rhodomonas salina cells that can be ingested by small ( $21.5 \mathrm{~mm}$ shell length) M. edulis before insipient saturation amounts to $11.4 \pm 1.7 \times 10^{6}$ cells, equivalent to a total volume of $2 \mathrm{~mm}^{3}$. However, filtration rates and responses to monospecies, cultured algae under laboratory conditions, may not accurately reflect in situ filtration where a wide spectrum of changing environmental factors may influence the feeding behaviour $[6,42]$. Natural seston consists of a broad mixture of plankton, bacteria, detritus, and inorganic materials and extrapolating from laboratory to field concentrations of chl $a$ should be done with caution when discussing "critical saturation concentrations." Therefore further test of the FCA including natural seston, perhaps spiked with $R$. salina, may be relevant in future studies.

The FCA has opened up for new detailed information on the filtration-reduction course during the first hour and up to 10 days following incipient saturation (Figures 5 and 7). In this context it is possible to reinterpret the filtration rate data obtained by Navarro and Winter [13] who performed experiments with Mytilus chilensis using the automatic recording apparatus described by Winter [12] and high algal (Dunaliella marina) concentrations of 15,000, 25,000, and 40,000 cells $\mathrm{mL}^{-1}$. The low specific filtration rates of $1.55,1.05$, and $0.79 \mathrm{~L} \mathrm{~h}^{-1} \mathrm{~g}^{-1}$ found by Navarro and Winter [13] may be compared to the specific rate of $7.37 \mathrm{~L} \mathrm{~h}^{-1} \mathrm{~g}^{-1}$ measured in Mytilus edulis by Riisgård and Møhlenberg [15] using a photoaquarium method and to $7.45 \mathrm{~L} \mathrm{~h}^{-1} \mathrm{~g}^{-1}$ measured by Møhlenberg and Riisgård [22] using the "suction method". Because the filtration rate experiments conducted by Navarro and Winter [13] "were carried out over 24 h," it seems likely that only saturation-reduced rates were recorded. In most of our experiments with $M$. edulis the filtration rate decreased to about $20 \%$ of the maximum rate when the mussels were exposed to algal concentrations between 6,800 and 10,900 Rhodomonas cells $\mathrm{mL}^{-1}$. At higher algal concentrations (Table 1, Group 3 at 19,700 and 36,100 cells $\mathrm{mL}^{-1}$ ) the filtration rate after $24 \mathrm{~h}$ was further reduced to $10 \%$ of maximum. The reduction in filtration rate could not be described by exponential curvefits $\left(R^{2}<0.5\right)$ in experiments A, D, F, I, and K (Table 1 and Figure 5). The reason why mussels in experiment $\mathrm{D}$ behaved differently from mussels in other experiments remains unexplained. A reduction of filtration rate has previously been found for M. edulis fed Phaeodactylum tricornutum at 15,000 to 40,000 cells $\mathrm{mL}^{-1}$ [39, Figure 3(a) therein] whereby the filtration rate was reduced to about $25 \%$ of maximum after 300 min irrespective of the algal concentration, indicating "no regulation of filtration rate to ambient algal concentration" [39]. Winter [12] found a further reduction of filtration rate by $50 \%$ in M. edulis when the algal concentration was increased from 20,000 to 40,000 Dunaliella marina cells $\mathrm{mL}^{-1}$. Kiørboe et al. [43] suggested "that M. edulis depends on suspended bottom material to exploit fully its clearance potential", but Clausen and Riisgård [10] showed that this may not be a prerequisite for mussels to achieve maximum growth. In turbid 
macrotidal waters, such as the Western Scheldt Estuary [44] and the Marsdiep in the western Wadden Sea [45], M. edulis may frequently be exposed to high concentrations of chl $a$ and suspended matter, and in such situations it remains unknown to what degree $M$. edulis may exploit its filtration rate capacity while also coping with cleaning of the gills and sorting of particles of food value, particularly phytoplankton, and particles without food value, particularly silt $[2,24,26,46-$ 50]. Finally, it should also be mentioned that other environmental factors in nature may influence the filtration rate, for example, flow-induced inhibition of filtration rate due to high ambient current velocity and turbulence (e.g., [51, 52]), salinity changes (e.g., $[53,54])$, and toxic algae $[55,56]$.

By passively controlling of the valve gape of Mytilus edulis Jørgensen et al. [57] found that the oxygen consumption rate was relatively uninfluenced until the filtration rate was reduced to about $20 \%$ of the maximum, but at further reduced filtration rates the oxygen consumption dramatically decreased. This indicates that in the present longterm experiment (Figure 7) where $M$. edulis reduced its filtration rate to about $12 \%$ the oxygen consumption may have been affected. Until recently it remained unknown if M. edulis is able to regulate its ingestion rate to ensure optimal growth during food-saturated conditions and partial valve closure or if optimal growth depends on unrestrained oxygen consumption (i.e., no reduction of respiration due to valve closure). Thus, using the FCA set-up Riisgård et al. [58] have run controlled growth experiments at constant algal concentrations both below and above the foodsaturation levels $\left(C_{\text {sat }}\right)$. From nearly constant filtration rates measured at algal concentrations below $C_{\text {sat }}$ the filtration rate decreased with increasing algal concentrations above $C_{\text {sat }}$ to only $10 \%$ of previous rate. The ingestion rate $(I=$ $F \times C$ ) increased linearly below $C_{\text {sat }}$, but the weight specific growth rates decreased sharply above $C_{\text {sat }}$ and a survey of naturally occurring phytoplankton biomass in the sea showed that this is generally below $C_{\text {sat }}$. Hence, Riisgård et al. [58] concluded that mussels may generally feed at optimal rates depending on the concentration of phytoplankton exceeding the minimal biomass below which the mussels cease filtering.

The present study on the effect of changing salinity on the filtration rate of mussels (Figures 8 and 9) has demonstrated that the FCA set-up may also be useful in acute environmental effect studies on mussels. Obviously, the FCA set-up is not limited to mussels but may be extended to oysters, scallops, and other species of filter-feeding zoobenthos (ascidians, polychaetes, bryozoans, sponges, etc.). The very precise conditions in laboratory studies like the present are never fully encountered in the natural environment and FCA-measured filtration rates should be compared- "intercalibrated" - with in situ type studies. For a wide application the FCA needs to be further tested with cells of various sizes, morphologies, and fluorescence properties, and it should also be tested how the FCA performs with mixed-species assemblages that may be difficult to maintain consistently for extended time periods. However, the examples and tests made in the present study demonstrate a significant potential of the FCA system.

\section{Conflict of Interests}

The authors declare no competing interests.

\section{Acknowledgments}

This work formed part of the MarBioShell project supported by the Danish Agency for Science, Technology and Innovation for the period from January 2008 to December 2012. Thanks are due to Bent Bach Andersen for technical support and guidance and to Professor Poul S. Larsen for constructive comments on the paper.

\section{References}

[1] C. R. Newell, D. E. Campbell, and S. M. Gallagher, "Development of the mussel aquaculture lease site model MUSMOD: a field program to calibrate model formulations," Journal of Experimental Marine Biology and Ecology, vol. 219, no. 1-2, pp. 143-169, 1998.

[2] C. R. Newell, D. J. Wildish, and B. A. MacDonald, “The effects of velocity and seston concentration on the exhalant siphon area, valve gape and filtration rate of the mussel Mytilus edulis," Journal of Experimental Marine Biology and Ecology, vol. 262, no. 1, pp. 91-111, 2001.

[3] P. Dolmer, "Algal concentration profiles above mussel beds," Journal of Sea Research, vol. 43, no. 2, pp. 113-119, 2000.

[4] H. U. Riisgård, "Physiological regulation versus autonomous filtration in filter-feeding bivalves: starting points for progress," Ophelia, vol. 54, no. 3, pp. 193-211, 2001.

[5] P. L. Pascoe, H. E. Parry, and A. J. S. Hawkins, "Observations on the measurement and interpretation of clearance rate variations in suspension-feeding bivalve shellfish," Aquatic Biology, vol. 6, no. 1-3, pp. 181-190, 2009.

[6] H. U. Riisgård, P. P. Egede, and I. B. Saavedra, "Feeding behaviour of mussels, Mytilus edulis: new observations, with a minireview of current knowledge," Journal of Marine Biology, vol. 2011, Article ID 312459, 13 pages, 2011.

[7] P. S. Larsen and H. U. Riisgård, "Validation of the flow-through chamber (FTC) and steady-state (SS) methods for clearance rate measurements in bivalves," Biology Open, vol. 1, no. 1, pp. 6-11, 2012.

[8] H. U. Riisgard and A. Randløv, "Energy budgest, growth and filtration rates in Mytilus edulis at different algal concentrations," Marine Biology, vol. 61, no. 2-3, pp. 227-234, 1981.

[9] E. Poulsen, H. U. Riisgård, and F. Møhlenberg, "Accumulation of cadmium and bioenergetics in the mussel Mytilus edulis," Marine Biology, vol. 68, no. 1, pp. 25-29, 1982.

[10] I. Clausen and H. U. Riisgård, "Growth, filtration and respiration in the mussel Mytilus edulis: no evidence for physiological regulation of the filter-pump to nutritional needs," Marine Ecology Progress Series, vol. 141, no. 1-3, pp. 37-45, 1996.

[11] H. U. Riisgård, "On measurement of filtration rates in bivalvesthe stony road to reliable data: review and interpretation," Marine Ecology Progress Series, vol. 211, pp. 275-291, 2001.

[12] J. E. Winter, "The filtration rate of Mytilus edulis and its dependence on algal concentration, measured by a continuous automatic recording apparatus," Marine Biology, vol. 22, no. 4, pp. 317-328, 1973.

[13] J. M. Navarro and J. E. Winter, "Ingestion rate, assimilation efficiency and energy balance in Mytilus chilensis in relation to 
body size and different algal concentrations," Marine Biology, vol. 67 , no. 3, pp. 255-266, 1982.

[14] R. J. Thompson and B. L. Bayne, "Some relationships between growth, metabolism and food in the mussel Mytilus edulis," Marine Biology, vol. 27, no. 4, pp. 317-326, 1974.

[15] H. U. Riisgård and F. Møhlenberg, "An improved automatic recording apparatus for determining the filtration rate of Mytilus edulis as a function of size and algal concentration," Marine Biology, vol. 52, no. 1, pp. 61-67, 1979.

[16] K. Haupt, "A simple device to control concentrations of food algae in feeding experiments with filter feeding organisms," in Veröffentlichungen des Instituts für Meeresforschung in Bremerhaven, vol. 17, pp. 241-244, 1979.

[17] H. H. Janssen and H. P. Dreyer, "A simple and cheap apparatus for the controlled feeding of suspension feeders," Marine Biology, vol. 62, no. 4, pp. 313-315, 1981.

[18] D. J. Hornbach, T. Wilcox, J. Layne, and T. Davis, "A method for assessing clearance rates in suspension-feeding organisms by means of a fiber-optic colorimeter," Canadian Journal of Zoology, vol. 69, no. 10, pp. 2703-2706, 1991.

[19] W. C. M. K. Breteler and M. Laan, "An apparatus for automatic counting and controlling density of pelagic food particles in cultures of marine organisms," Marine Biology, vol. 116, no. 1, pp. 169-174, 1993.

[20] S. M. Gallager and R. Mann, "An apparatus for the measurements of grazing activity of filter feeders at constant food concentrations," Marine Biology Letters, vol. 1, pp. 341-349, 1980.

[21] B. Rico-Villa, P. Woerther, C. Mingant et al., "A flow-through rearing system for ecophysiological studies of Pacific oyster Crassostrea gigas larvae," Aquaculture, vol. 282, no. 1-4, pp. 5460, 2008.

[22] F. Møhlenberg and H. U. Riisgård, "Filtration rate, using a new indirect technique, in thirteen species of suspension-feeding bivalves," Marine Biology, vol. 54, no. 2, pp. 143-147, 1979.

[23] J. Coughlan, "The estimation of filtering rate from the clearance of suspensions," Marine Biology, vol. 2, no. 4, pp. 356-358, 1969.

[24] C. B. Jørgensen, Bivalve Filter Feeding: Hydrodynamics, Bioenergetics, Physiology and Ecology, Olsen \& Olsen, Fredensborg, Denmark, 1990.

[25] H. U. Riisgård, B. H. Jørgensen, K. Lundgreen et al., "The exhalant jet of mussels Mytilus edulis," Marine Ecology Progress Series, vol. 437, pp. 147-164, 2011.

[26] T. Kiørboe and F. Møhlenberg, "Particle selection in suspension-feeding bivalves," Marine Ecology Progress Series, vol. 5, pp. 291-296, 1981.

[27] K. Sand-Jensen, S. L. Nielsen, J. Borum, and O. GeertzHansen, "Phytoplankton and macrophyte development in Danish coastal waters (in Danish with English summary)," in Havforskning fra Miljøstyrelsen, vol. 30, Miljøministeriet, Copenhagen, Denmark, 1994.

[28] A. Hatcher, J. Grant, and B. Schofield, "Effects of suspended mussel culture (Mytilus spp.) on sedimentation, benthic respiration and sediment nutrient dynamics in a coastal bay," Marine Ecology Progress Series, vol. 115, no. 3, pp. 219-237, 1994.

[29] A. Hatcher, J. Grant, and B. Schofield, "Seasonal changes in the metabolism of cultured mussels (Mytilus edulis L.) from a Nova Scotian inlet: the effects of winter ice cover and nutritive stress," Journal of Experimental Marine Biology and Ecology, vol. 217, no. 1, pp. 63-78, 1997.

[30] İ. Okumuş and H. P. Stirling, "Seasonal variations in the meat weight, condition index and biochemical composition of mussels (Mytilus edulis L.) in suspended culture in two Scotish sea lochs," Aquaculture, vol. 159, no. 3, pp. 249-261, 1998.

[31] N. Rask, S. E. Pedersen, and M. H. Jensen, "Response to lowered nutrient discharges in the coastal waters around the island of Funen, Denmark," Hydrobiologia, vol. 393, pp. 69-81, 1999.

[32] P. Garen, S. Robert, and S. Bougrier, "Comparison of growth of mussel, Mytilus edulis, on longline, pole and bottom culture sites in the Pertuis Breton, France," Aquaculture, vol. 232, no. 1-4, pp. 511-524, 2004.

[33] J. Ojea, A. J. Pazos, D. Martínez, S. Novoa, J. L. Sánchez, and M. Abad, "Seasonal variation in weight and biochemical composition of the tissues of Ruditapes decussatus in relation to the gametogenic cycle," Aquaculture, vol. 238, no. 1-4, pp. 451468, 2004.

[34] T. G. Nielsen and M. Maar, "Effects of a blue mussel Mytilus edulis bed on vertical distribution and composition of the pelagic food web," Marine Ecology Progress Series, vol. 339, pp. 185-198, 2007.

[35] J. L. Iriarte, H. E. González, K. K. Liu, C. Rivas, and C. Valenzuela, "Spatial and temporal variability of chlorophyll and primary productivity in surface waters of southern Chile (41.5$43^{\circ}$ S)," Estuarine, Coastal and Shelf Science, vol. 74, no. 3, pp. 471-480, 2007.

[36] T. Strohmeier, Ø. Strand, M. Alunno-Bruscia, A. Duinker, and P. J. Cranford, "Variability in particle retention efficiency by the mussel Mytilus edulis," Journal of Experimental Marine Biology and Ecology, vol. 412, pp. 96-102, 2012.

[37] M. Frechette, C. A. Butman, and W. R. Geyer, "The importance of boundary-layer flows in supplying phytoplankton to the benthic suspension feeder, Mytilus edulis L.," Limnology \& Oceanography, vol. 34, no. 1, pp. 19-36, 1989.

[38] H. U. Riisgård, J. Lassen, and C. Kittner, "Valve-gape response times in mussels (Mytilus edulis)—effects of laboratory preceding-feeding conditions and in situ tidally induced variation in phytoplankton biomass," Journal of Shellfish Research, vol. 25, no. 3, pp. 901-911, 2006.

[39] H. U. Riisgård, "Filtration rate and growth in the blue mussel, Mytilus edulis Linneaus, 1758: dependence on algal concentration," Journal of Shellfish Research, vol. 10, no. 1, pp. 29-35, 1991.

[40] J. K. Petersen and H. U. Riisgard, "Filtration capacity of the ascidian Ciona intestinalis and its grazing impact in a shallow fjord," Marine Ecology Progress Series, vol. 88, no. 1, pp. 9-17, 1992.

[41] H. U. Riisgård and N. M. Ivarsson, “The crown-filament-pump of the suspension-feeding polychaete Sabella penicillus: filtration, effects of temperature, energy cost," Marine Ecology Progress Series, vol. 62, pp. 249-257, 1990.

[42] B. A. MacDonald and J. E. Ward, "Feeding activity of scallops and mussels measured simultaneously in the field: repeated measures sampling and implications for modelling," Journal of Experimental Marine Biology and Ecology, vol. 371, no. 1, pp. 4250, 2009.

[43] T. Kiørboe, F. Møhlenberg, and O. Nøhr, "Effect of suspended bottom material on growth and energetic in Mytilus edulis," Marine Biology, vol. 61, no. 4, pp. 283-288, 1981.

[44] J. C. Kromkamp and T. van Engeland, "Changes in phytoplankton biomass in the western scheldt estuary during the period 1978-2006," Estuaries and Coasts, vol. 33, no. 2, pp. 270-285, 2010.

[45] C. J. M. Philippart, J. M. van Iperen, G. C. Cadée, and A. F. Zuur, "Long-term field observations on seasonality in chlorophylla concentrations in a shallow coastal marine ecosystem, the 
Wadden Sea," Estuaries and Coasts, vol. 33, no. 2, pp. 286-294, 2010.

[46] R. L. Foster-Smith, "The effect of concentration of suspension on the filtration rates and pseudofaecal production for Mytilus edulis L., Cerastoderma edule(L.) and Venerupis pullastra (Montagu)," Journal of Experimental Marine Biology and Ecology, vol. 17, no. 1, pp. 1-22, 1975.

[47] P. G. Beninger and S. D. St-Jean, "The role of mucus in particle processing by suspension-feeding marine bivalves: unifying principles," Marine Biology, vol. 129, no. 2, pp. 389-397, 1997.

[48] H. Scholten and A. C. Smaal, "Responses of Mytilus edulis L. to varying food concentrations: testing EMMY, an ecophysiological model," Journal of Experimental Marine Biology and Ecology, vol. 219, no. 1-2, pp. 217-239, 1998.

[49] E. Gosling, Bivalve Molluscs. Biology, Ecology and Culture, Fishing News Books, Blackwell, Okla, USA, 2003.

[50] J. E. Ward and S. E. Shumway, "Separating the grain from the chaff: particle selection in suspension- and deposit-feeding bivalves," Journal of Experimental Marine Biology and Ecology, vol. 300, no. 1-2, pp. 83-130, 2004.

[51] D. J. Wildish and M. P. Miyares, "Filtration rate of blue mussels as a function of flow velocity: preliminary experiments," Journal of Experimental Marine Biology and Ecology, vol. 142, no. 3, pp. 213-219, 1990.

[52] D. J. Wildish and D. D. Kristmanson, "Hydrodynamic control of bivalve filter feeders: a conceptual view," NATO ASI Series, vol. 33, pp. 297-324, 1993.

[53] P. C. Almada-Villela, "The effects of reduced salinity on the shell growth of small Mytilus edulis," Journal of the Marine Biological Association of the United Kingdom, vol. 64, no. 1, pp. 171-182, 1984.

[54] H. U. Riisgård, L. Bøttiger, and D. Pleissner, "Effect of salinity on growth of mussels, Mytilus edulis, with special reference to Great Belt (Denmark)," Open Journal of Marine Science, vol. 2, pp. 167-176, 2012.

[55] L. Chauvaud, G. Thouzeau, and Y. M. Paulet, "Effects of environmental factors on the daily growth rate of Pecten maximus juveniles in the Bay of Brest (France)," Journal of Experimental Marine Biology and Ecology, vol. 227, no. 1, pp. 83-111, 1998.

[56] L. Chauvaud, F. Jean, O. Ragueneau, and G. Thouzeau, "Longterm variation of the Bay of Brest ecosystem: benthic-pelagic coupling revisited," Marine Ecology Progress Series, vol. 200, pp. 35-48, 2000.

[57] C. B. Jørgensen, F. Møhlenberg, and O. Sten-Knudsen, "Nature of relation between ventilation and oxygen consumption in filter feeders," Marine Ecology Progress Series, vol. 29, pp. 73-88, 1986.

[58] H. U. Riisgård, D. Pleissner, K. Lundgreen, and P. S. Larsen, "Growth of mussels Mytilus edulis at algal (Rhodomonas salina) concentrations below and above saturation levels for reducted filtration rate," Marine Biology Research, vol. 9, no. 10, pp. 10051017, 2013. 

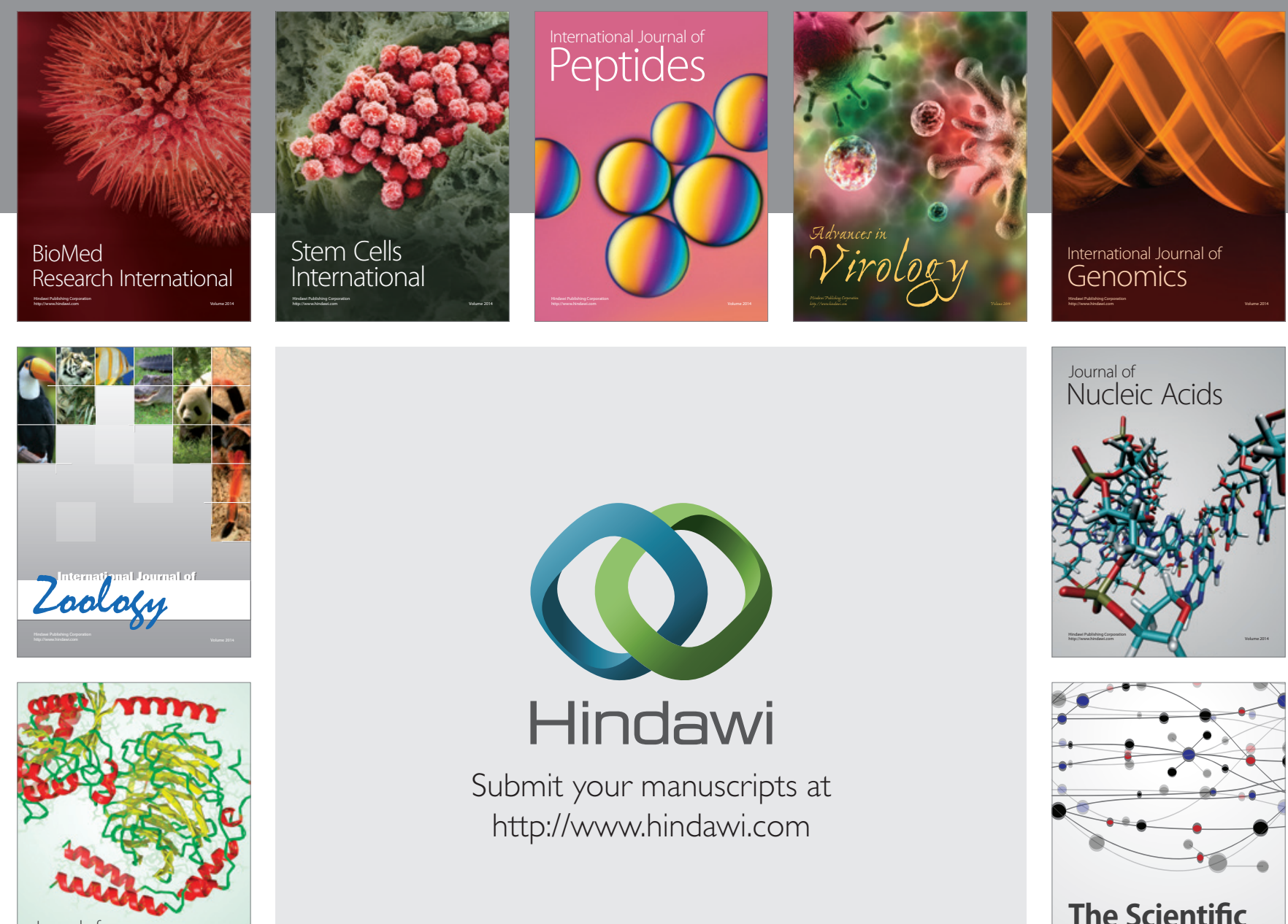

Submit your manuscripts at

http://www.hindawi.com

Journal of
Signal Transduction
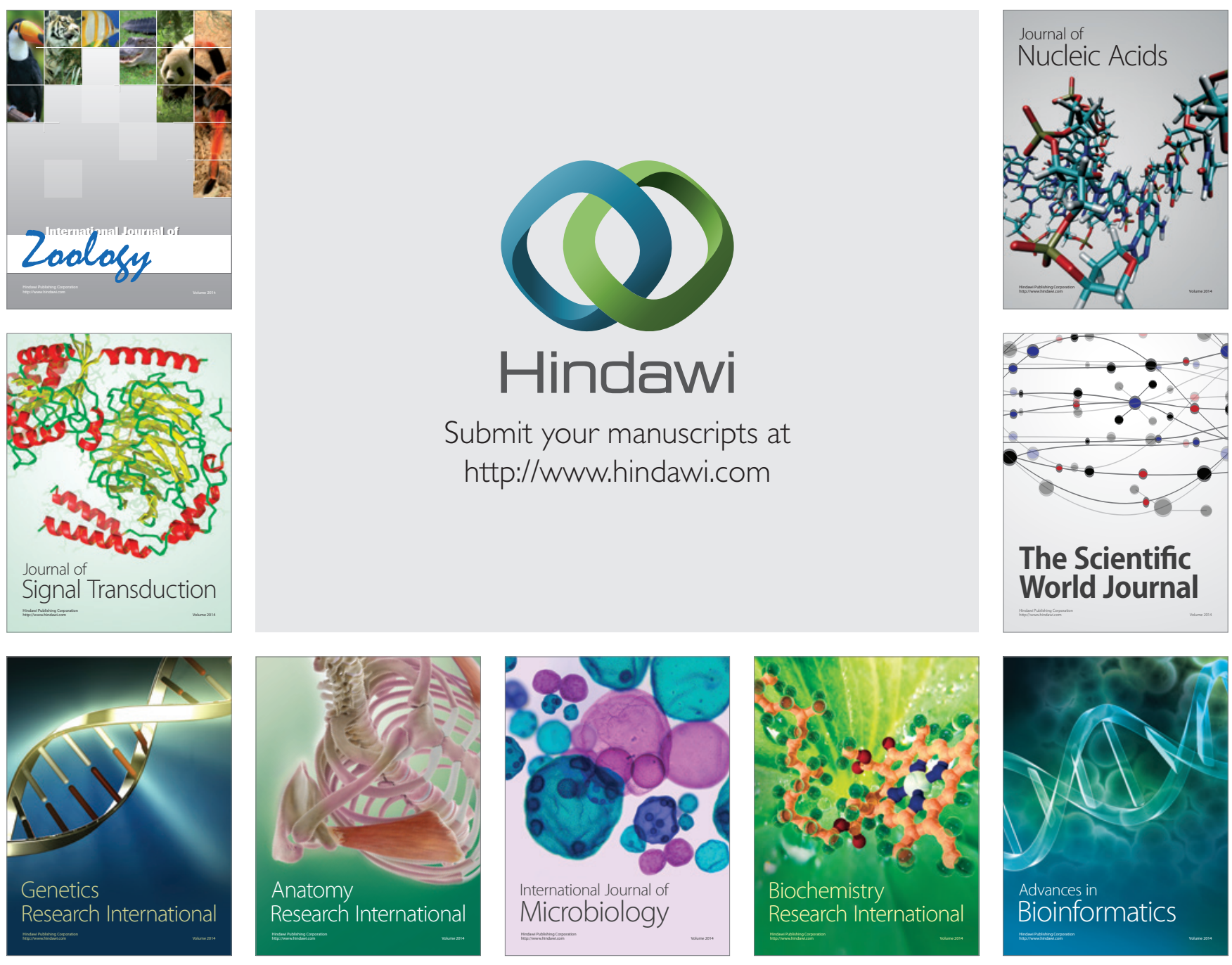

The Scientific World Journal
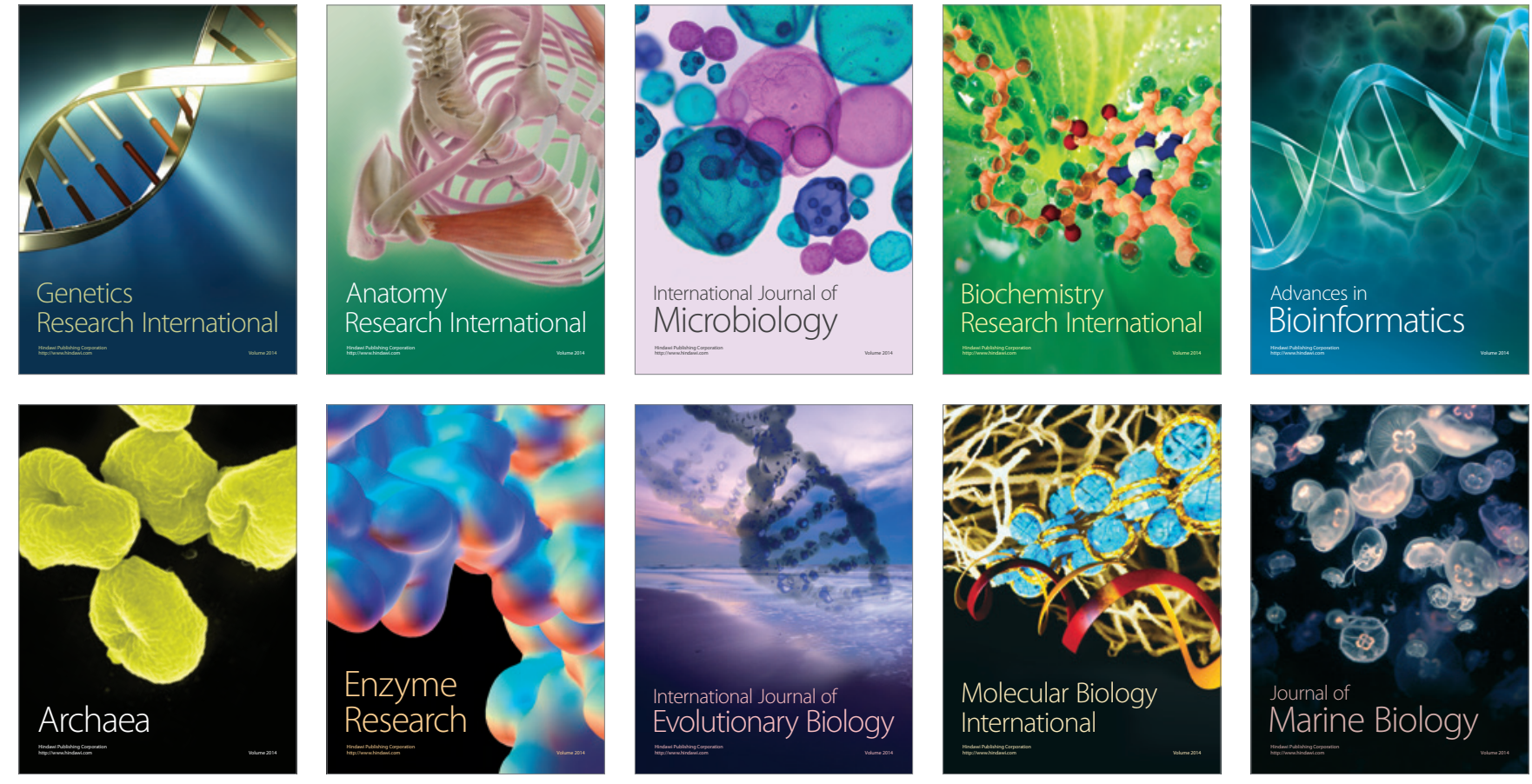